
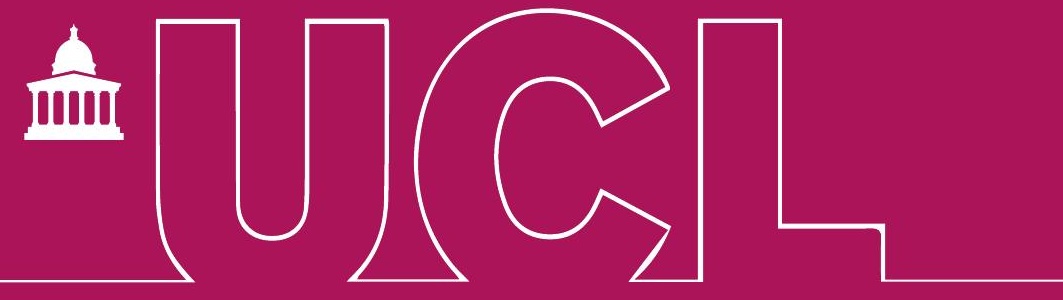

\title{
TOWARDS PROSPERITY:
}

\section{REINVIGORATING LOCAL ECONOMIES}

\section{THROUGH UNIVERSAL BASIC SERVICES}

Professor Henrietta L. Moore

and Hannah Collins

Working paper 01-2020/04 


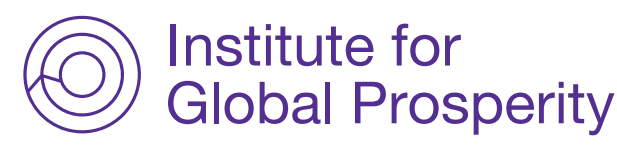

The IGP's vision is to help build a prosperous, sustainable, global future, underpinned by the principles of fairness and justice, and allied to a realistic, long-term vision of humanity's place in the world. The IGP undertakes pioneering research that seeks to dramatically improve the quality of life for this and future generations. Its strength lies in the way it allies intellectual creativity to effective collaboration and policy development. Of particular importance to the IGP's approach is the way in which it integrates non-academic expertise into its knowledge generation by engaging with decision-makers, business, civil society, and local communities.

For further information please contact: igp@ucl.ac.uk

To be cited as: Moore H.L. \& Collins H. (2020) Towards Prosperity: Reinvigorating Local Economies Through Universal Basic Services, London: Institute for Global Prosperity.

DOI: 10.14324/000.wp.10096789 


\title{
TOWARDS PROSPERITY1: REINVIGORATING LOCAL ECONOMIES THROUGH UNIVERSAL BASIC SERVICES
}

\author{
Professor Henrietta L. Moore and Hannah Collins
}




\section{PREFACE}

As we enter a new decade the future is increasingly uncertain. This paper focuses on interpreting existing research on localism and the foundational economy in light of recent discussions concerning Universal Basic Services (IGP, 2017; 2019a; Coote \& Percy, 2020). We argue that localisation of basic services should form the basis of a new industrial strategy for the 2020's. Investment in the infrastructure of care, health, education, transport and communication would increase people's capacities, capabilities and opportunities for economic and social participation. These engines of investment improve people's quality of life at the local level and regenerate local economies. By bringing localisation of basic services to the heart of a new industrial strategy control would return to places and people and help to secure livelihoods ${ }^{2}$ in the face of broad technological and societal change.

\section{KEYWORDS}

localism; universal basic services; foundational economy; prosperity; industrial strategy

\section{CONTACT}

E-mail : hannah.collins.16@ucl.ac.uk

Address : Hannah Collins, Institute for Global Prosperity, Maple House, 149 Tottenham Court Rd, London W1T 7NF

${ }^{2}$ Secure livelihoods are a necessary foundation for prosperity. Highlighted by research coming out of the Institute for Global Prosperity which found prosperity is understood by citizens in east London, 'as the pursuit of a good life - a secure livelihood, good quality work, functioning public services, choice, opportunity, political freedoms, [and] intergenerational justice,' (Moore \& Woodcraft, 2019: 294). 


\section{TABLE OF CONTENTS}

Preface

Keywords

Contact

Acknowledgements

1. Introduction

2. Localism

2.1 Why progressive localism is key

2.2 Localism and participation

2.3 Localism and ownership

3. Preston: Case Study

4. Connecting Universal Basic Services and the foundational economy

4.1 What is the foundational economy?

4.2 FE from framing and prioritising UBS

4.3 Taxation

5. Connecting these concepts in an industrial strategy for the 21st century

5.1 The future of UBS

Conclusion: Prosperity through the localisation of services 


\section{ACKNOWLEDGEMENTS}

Thank you very much to Chris Harker, Andrew Percy, Saffron Woodcraft, Juan Moreno, Sarah Nisi, and Nikolay Mintchev for their insights, comments, edits and support.

\section{ABOUT THE INSTITUTE OF GLOBAL PROSPERITY}

The Institute for Global Prosperity aims to rethink what prosperity means for people around the globe. Our vision is to help build a prosperous, sustainable, global future, underpinned by the principles of fairness and justice, and allied to a realistic, longterm vision of humanity's place in the world. The IGP undertakes pioneering research that seeks to dramatically improve the quality of life for current and future generations. Its strength lies in the way it allies intellectual creativity to effective collaboration and policy development. Of particular importance to the IGP's approach is the way in which it integrates non-academic expertise into its knowledge generation by engaging with decision-makers, business, civil society, and local communities. 


\section{INTRODUCTION}

Since the mid-seventies the economic path in the United Kingdom has shifted from one of convergence to divergence. Inequality has grown in the last fifty years by the promotion of narrow economic policy that embeds top-down priorities, the richest 0.1 per cent now take 67 times the mean income (Dorling, 2019). Public policy is debated and created among technical and political elites, and policy adherence to GDP growth has not resulted in quality of life outcomes for the majority. Public services have been eroded. Austerity, far from delivering reductions in public spending has generated additional social costs. Over a million people are using food banks (Trussell Trust, 2019), rough sleeping has doubled (The Economist, 2018), and one in three children and around one in five pensioners have dropped below the poverty line (DWP, 2019). The shift to neoliberalism, evoking individualism and competition, has coincided with a rise in psychiatric conditions such as self-harm, eating disorders, depression and personality disorders (Verhaeghe, 2014), and in 'deaths of despair' (Joyce \& Xu, 2019). Despite the fact that employment in the UK has reached a record high since 1979 (ONS, 2020), British workers are economically insecure. Workers increasingly feel that their income does not provide them with enough to maintain a decent standard of living - 30 per cent up from 26 per cent in 2017. Notably, 36 per cent of workers, many of whom are in steady jobs, would struggle to pay an unexpected bill of $£ 100$, and 59 per cent would struggle to pay an unexpected bill of $£ 500$ (Wallace-Stephens, 2019). Shadowing all of this is climate collapse.
This begs the question, how well is the economy serving society? The economy is not out of human control; it is a societal construct that humans have shaped, developed and adhered to. There have been several calls for a vision of the economy that is inclusive, and based on recognising that communities and people are active players in wealth creation. In 2017 the UK's Industrial Strategy Commission recommended further and faster devolution to town cities and regions, alongside what they describe as 'human capital building universal services' (Industrial Strategy Commission, 2017: 3). This is a welcome proposition. New models of innovation should focus on creating public value through local economic engagement. We argue that an industrial policy for the 2020's would focus on enhancing the services and foundations we already have with the goal of prosperity for everyone.

The ideas presented in this paper are closely tied to the Institute for Global Prosperity's Social Prosperity Network proposal for Universal Basic Services (UBS) which builds on existing public services, namely the National Health Service and education, and argues for more and better collectively provided services free for all who need them, including social care, housing, transport and access to digital information (IGP, 2017; 2019a). It argues for the delivery of services to be localised, with the state playing a central role in access and delivery. It is a call for solidarity, collective policy and practice to deal with risks and problems that individuals cannot afford to pay for or deal with alone. 
By exploring the local drivers of a new industrial strategy through UBS, this paper aims to highlight avenues to prosperity for the UK. The statistics surrounding 'broken Britain' are depressing. And at the beginning of a new decade, rather than feeling invigorated, there is a sense of foreboding of what is to come. However, our shared challenges offer an opportunity to restructure our economy into one that works for all of us, not just the top one per cent. What we present here are examples of what is working around the UK, and how, through reworking our industrial strategy to focus on localism we can secure services, livelihoods, wellbeing, health and education as we enter the uncertain future ahead. First, we explore localism - what it is and why it is key to future prosperity in the UK. Then we turn to the foundational economy (FE) - what it is and why it is key for future job security and service delivery. We connect the concepts for an industrial strategy that is fit for the 21st century and look to the future of UBS. Throughout the paper we link back to UBS and argue that what is needed is the creation of engines of investment to improve people's quality of life at the local level, to regenerate local economies and enhance people's capabilities and capacities in the face of future uncertainty. 


\section{LOCALISM}

While there are many calls for localism there is a lack of consensus in defining and interpreting it in practice. Nonetheless, there is a growing consensus for the need to revisit the inherited spatial architecture that underpins politics (Wills, 2016; Industrial Strategy Commission, 2017). Placebased strategy is a key component of the European Union’s 2020 ‘Innovation Union’ programme (Bailey, Pitelis \& Tomlinson, 2018) and of the UK's Industrial Strategy (HM Government, 2017). The OECD (2019) argues that a more decentralised ${ }^{3}$ approach to government correlates with stronger growth, more social investment, better educational outcomes, political stability and less regional inequality. They argue decentralisation is especially crucial in the current context of a 'geography of discontent' characterised by growing divides between places that are 'left behind' by globalisation and technological change and those that benefit from them (OECD, 2019, p. 11).

Localism discourse is being mobilised across the political spectrum to justify policy, promising greater economic efficiency and administration and to enhance democracy by linking the local to a more responsive form of governance (Painter et al., 2011). For the political right, localism is a way to grow the local and national economy through a 'Big Society' (David Cameron, 2010), and on the left, it is a way for people to work with the state to initiate social change (Wills, 2016). The 'Big Society' was to be a means through which to empower communities to deal with cuts to public spending and was a response to a perceived crisis of trust in the British political system after the financial crisis. Subsequent academic debates have examined the extent to which this type of localism and the 'Big Society' have provided further fuel of the neoliberal project in an era of austerity (Levitas, 2012; Newman, 2013). On the political right localism is a mechanism to govern from a distance through the imposition of morally charged discourse associated with fairness, naturalness, efficiency and democracy (Tait \& Inch, 2016).

The Localism Act of 2011 (Department of Communities and Local Government, 2011) recognised that while the national government sets the standard for social wellbeing, the implementation of the different functions would be better undertaken at a local level. Neighbourhood planning enshrined in the Localism Act designates forums that can prepare neighbourhood plans which upon adoption become part of the statutory planning schema. The policy of neighbourhood planning was introduced to overcome the idea that community opposition to housebuilding was one of the key factors in the decline of new

\footnotetext{
${ }^{3}$ Decentralisation refers to a transfer of power and responsibilities from central government to the elected authorities at the subnational level that have some degree of autonomy. It covers three interrelated dimensions: political, administrative and fiscal (OECD, 2019).
} 
housing supply. By giving communities the right to draw up neighbourhood plans they would in turn support a pro-growth agenda and increase housing stock. Neighbourhood planning is emerging as a proponent of sustainability and social purpose within the housing market, conflicting with cooperate interests of liberalised housing markets (Bradley \& Sparling, 2016). But the Localism Act has had little effect on changing the balance of power between Whitehall and local authorities, because of concurrent and extensive reductions in local government finance (Bevan, 2014; Hastings et al., 2015). But the Localism Act has had little effect on changing the balance of power between Whitehall and local authorities, because of concurrent and extensive reductions in local government finance (Bevan, 2014; Hastings et al., 2015).

Recent forms of devolution have been embedded within a centrally imposed tax cutting agenda. Devolution in times of austerity can lead to real threats when forsaking one service for another by ‘joining up' policy (Tomaney, 2016). The devolution of business rates works to advantage areas which already have the means to attract new businesses that can go on to expand their tax base, fund local initiatives and infrastructure which, in the absence of fiscal solidarity, leads to greater regional inequality. Rather than enhancing democracy this type of devolution is designed to improve only a narrow set of business interests through few democratic checks (Tomaney, 2016). Devolution is unlikely to be successful across all regions, in places where people lack the capacity or interest to respond, and so are likely to be disadvantaged further (Wills, 2016). We need a national constitutional conversation to reshape local government so that it 'sits alongside central government as a co-director of the nation,' (CLES, 2019, August: 2).

Governments have failed to confront social and economic problems causing responsibility to informally devolve downwards to cities and metropolitan areas. While official power remains vested in central governments, limiting the ability of local leaders to tailor solutions to the needs and conditions of the locality. As such, localism in its myriads can be tokenistic, hijacked by a neoliberal agenda. At the same time, a more progressive form of localism represents a desire and need for a new way of organising and imagining society.

\subsection{WHY PROGRESSIVE LOCALISM IS THE KEY}

Decentralisation combined with the appreciation of local needs, cultural identities and political representation has informed agenda's in environmental conservation, feminism, postcolonialism and international development (Painter et al., 2011). Hess (2009: 7) defines localism as 'the movement in support of governmental policies and economic practices oriented toward enhancing local democracy and local ownership of the economy'. Highlighting the belief that locally self-reliant economies are less susceptible to economic fluctuations and decisions of large corporations. Some research also suggests that communities with high concentrations of small, locally owned businesses experience higher economic growth (Fleming \& Goetz, 2011). It can be thought of as a movement to reconfigure the geographical division of political power by shifting central power to the localities (Maas, 1959). The geography of a place provides the ground for people to form new ways of relating to one another and state-funded bodies and politicians.

Featherstone and colleagues (2012) differentiate between 'austerity localism' and 'progressive localism.' Austerity localism, as described above, is part of the broad practice of governments who have constructed the local as antagonistic to the state and invoked it to restructure the public sector, as 'roll-back' neoliberalism (Featherstone et al., 2012). Progressive localism 'denotes a political sensibility that does not cede the language of localism to the political right and instead experiments in placedbased political activity that both challenges morally conservative and neoliberal articulations or localism, and generates new expressions of social justice and participation,' (Findlay-King et al., 2018: 159). 
Localism can be a response to an expanded state presence, faltering service provision and lack of civic control and engagement in political life. The reforms associated with localism are designed to impact both sides of the current system. From one side, impacting the way the state functions, and from the other side changing the way citizens act and engage with political life. Progressive localism means a shift from control over a population to control by the population, allowing a diversity of spaces, actors, politics and governments to have freedom to determine their own needs (Wills, 2016). It is about citizens having the capacity to solve their own problems, and is an argument for community organising and participatory democracy. Linked to Sen's idea of capabilities, capacities and the crucial role of public deliberations (Sen, 1999).

In contrast to the 'Big Society,' progressive localism goes beyond restricted devolution to regional levels. UBS calls for 'devolution to the lowest appropriate level (according to the principle of subsidiarity),' (Coote \& Percy, 2020: 33). It is an argument on the limits of central government providing for and responding to people's needs. Power is held at the lowest level in individuals, neighbourhoods, communities and local institutions. In this sense localism is top-down where reforms to responsibility, funding and authority are taken by those at higher levels and passed down to local authorities. At the same time progressive localism is bottom-up as people use their own knowledge to respond to the needs of their places (Wills, 2016).

The politics and economics of place were visible in the 2019 General Election. Seats across the North of England, the Midlands and Wales switched from Labour to the Conservatives - the 'Blue Wall' - determining the election result (McCurdy et al., 2020). These seats are behind new government's policy of 'levelling up,' aimed at narrowing the gaps between the poorest and richest areas of the country. The Resolution Foundation investigated the economy and demography of these regions and found that the situation is more nuanced than the popular story of 'left behind' towns. While the
'Blue Wall' has below average incomes, it is not the poorest region. But higher income constituencies are more unequal. Since 2010 the 'Blue Wall' regions have experienced weak labour market performance, with employment growing slower and pay falling further than across the rest of the North, Midlands and Wales. Although they have higher gross property wealth than in Labour seats in the regions, they are more exposed to recent Universal Credit benefit cuts than other Conservative seats. This constituency is middle-aged, characterised by low population dynamism and growth. Contrary to the popular narrative, people are not moving away in droves or commuting to access high-paid jobs. People are more likely to commute by car and less likely to work outside their local authority. Set alongside a low skills profile, the regions prospects for improving their life chances are at risk (McCurdy et al., 2020).

In response to these findings, the Resolution Foundation argue for a policy agenda that will 'clearly be different in places, highlighting the overlap between a levelling up agenda and a devolution one,' (McCurdy et al., 2020: 11). Investment is needed within not just between places to enhance capacities and capabilities of citizens through life-long learning and care, and public transport to connect people to places with jobs close by. The Joseph Rowntree Foundation have shown that reliable and affordable local buses are crucial for the economic development of "left behind' areas and require institutional attention and support to improve provision (Crisp et al., 2018).

Localism in variants such as local

government reform, devolution and

participatory governance is seen to

bring about some forms of community

empowerment but conditionally, based on citizen participation in the practices of local government.

(Painter et al., 2011) 
Localism will work best where there is local interest and capacity for engagement, such as local leadership, a culture of relationship building and existing local structures and institutions to connect people. It depends on the ability of local institutions to listen, represent and negotiate with the state for their local interests (Wills, 2016). Everyday knowledge 4 as a feature of participation is thus central to progressive localism.

\subsection{LOCALISM AND PARTICIPATION}

Pathways for democratic participation and citizen voice is fundamental to solving inequalities (Sen, 1999) and for prosperity (Moore, 2015; Moore \& Woodcraft, 2019). The current form of devolution has not been met with an enhancement of citizen knowledge in how the economy functions, one reason why the local agenda to date has largely been unsuccessful in reducing inequalities within and between regions. The Bank of England's Andy Haldane (2017: 2) argued, 'if economics or economic policy is elitist and inaccessible to most people, it is not doing its job. That is because the economy and economic policy affects most people's lives, every day of their lives.' He states that economics is facing a 'twin deficit' - in public understanding and public trust, inextricably intertwined and reinforcing one another. A 2016 YouGov poll showed only 12 per cent of respondents felt that politicians and the media talk about economics in a way that is accessible and easy to understand (YouGov, 2016). ${ }^{5}$ A survey of trust in the profession ranked economists second bottom, only higher than politicians (YouGov, 2017). Localising politics and economics would help to ignite what is lacking in our democracy today; increasing accessibility and trust through public engagement, knowledge and insights into the very systems with which we are embedded.

If politics is to work for everyone, it is important that people understand how the economy works. In order for to regain trust people need to be involved in political insitutions, not turned away from them. For localism to have a future, 'local governments will have to be opened up such that people come to see it as an arena through which they can raise local concerns and negotiate for change...citizens will come to see the entitlements of their citizenship as partly produced by their own actions in the local arena rather than being handed from high,' (Wills, 2016: 70). The state can offer support, but policy agendas and service delivery need to come from the communities they are working for.

One challenge to localism is the entrenched centralisation in the geo-constitution of the UK, its political practices, culture and the production of citizenship. Another is the lack of popular experience and governmental practice of local political capacity (Wills, 2016: 45). These hurdles will be hard to overcome even with the gaining momentum for greater local democracy, autonomy and civic engagement. Central government can look to devolved local governments in Wales, for example, who have been able to start implementing progressive policies specific to their needs. Or to the success of Ireland's Citizens' Assembly on abortion. For localisation to work local governments must overcome a dependency culture and rediscover their power; "[a]ny future revitalisation of local government will depend in the first instance on local actors of various hues exploiting opportunities and creating a permissive environment from the bottom up,' (Davis, 2008: 5).

${ }^{4}$ Everyday knowledge is a medium for organising the everyday experiences of individuals and social groups (Flick, 1994).

${ }^{5}$ The campaign 'Economy' started as a result of the YouGov poll (Economy, n.d.). They host free public courses on understanding economics, which most of us cannot make informed decisions on because of barriers to understanding. 'Economy' is an example of how education should continue throughout life, so we can engage with that which govern our lives. 
Everyday knowledge is a key feature of participation. Hilary Wainwright (2018) argues that connecting ordinary culture to our everyday knowledge can form the basis of a work-in-progress type of collective political agency. This practical knowledge forms the foundation of her 'new politics from the left' which encompasses new ways of understanding politics and economics on the basis of cultural, economic and social equality. As opposed to the historical prominence of the 'professional expert' in politics and economics which deny the tacit knowledge of ordinary people (Wainwright, 2018). Connecting Wainwright's contribution to UBS - everyday knowledge is essential to meaningful participation in designing and delivering services by services users in partnership with professionals and frontline workers (Coote \& Percy, 2020). Thus, respecting the rights of people to come up with new ideas, collectively.

Participation is central to UBS. 'We are seeking to overhaul the traditional model of public services so that they are genuinely participative, controlled by the people who need and use them, and supported rather than always directly provided by the state,' (Coote and Percy, 2020: 5). A lot depends on power relations and how far the power actually does shift to residents and services users. Effective participation would require an upskilling of all stakeholders, in a move towards co-production. Co-production involves service users and providers forming an equal partnership and combining experiential and codified knowledge to develop ways of meeting needs. This means people using everyday knowledge to identify needs and the best way to meet them, and in design and delivery of services.

A shift in the culture of 'caring for' to a culture of enabling.

(Boyle et al., 2013)
The dominant societal trend towards inequality, population mobility, cultural diversity and declining membership in civil society organisations increases the challenge of public engagement in politics (Wills, 2016). A loss of trust in institutions is important because it represents a breach in the social contract and signals erosion in social capital (Haldane, 2017). Increasing trust in the economic system by enhancing participation through everyday knowledge to deliver UBS can work to address divisive politics populating the UK and deepen democracy. Going forward localism will need support from central government to enhance capacities of the localities, to distribute funds and ensure standards and access of UBS. Funding and participation are often interdependent (IGP, 2019a). To succeed localism needs a more extensive and expensive, long-term policy than what is currently proposed (Ware, 2012).

\subsection{LOCALISM AND OWNERSHIP}

The issue of ownership is central to localism and service delivery, because who owns a service is a decisive factor in whose interests they represent. There is no evidence that the interests of private profit easily coincide with public interest in delivery of services, but plenty of evidence that points to successful alternatives (Angel, 2014; Hall, 2019). Beyond state ownership, there is a wide range of models for organisations providing services: social enterprises, cooperatives and mutuals, user-led organisations, registered charities, community and neighbourhood groups, shared interest groups. Partnerships can be formed between public bodies and NGOs to deliver services (Angel, 2014).

Local or civic ownership is not only a more efficient use of taxpayer's money it can also lead to better public services. Local government is geographically closer to citizens and frontline workers, and better placed to respond to priorities to provide integrated services (Angel, 2014). Around the UK local councils are finding ways to take (back) control of their energy, water and broadband supplies. 'Robert Hood Energy' in Nottingham and 'Thameswey Energy' in Woking are entirely council-owned and 
provide energy and gas as not-for-profits. In Bath, energy, gas, water and sewer services are owned and managed through a community trust, while in Brighton energy is provided through the 'Brighton Energy Cooperative.' Community projects, social enterprises and new models of ownership will give us back control and attachment.

The state has a crucial role to play delivering services through new models of public ownership. Services that are more participatory and relational can be achieved by utilising and valuing the primary sources of innovation available to the public sector - namely the knowledge of frontline staff and citizens (Angel, 2014). If we rethink the remits of the public sector beyond orthodoxies, working at local levels creates space for innovation and makes people participants rather than recipients which can succeed where more traditional approaches fail ${ }^{6}$.

In the management of potential conflicts of interests and redistribution between different localities we argue for a key role of the state, in line with Coote and Percy (2020) and the Industrial Strategy Commission (2017). But all organisations, public or private, that are contract to provide goods and services to the public, should share the same set of public interest goals such as equality, participation, quality, transparency (FEC, 2018) and prosperity.

With an ever increasing globalised and connected world, where people of one place feel more closely connected to those on the other side of the world than they do to their neighbours, the promotion of localism may seem counterintuitive. But we do not need inward looking views to act locally. Our places can provide us with motivation to engage with change and capacity to do so.

\footnotetext{
${ }^{6}$ This is not a case against the importance of central government. Nor is it trying to escape the terrain of the global, globalisation is here to stay but we need an alternative to its current neoliberal form. Globalisation is the outcome of direct political decision making, not to be misled by a myth of technological inevitability. A globalisation that is better governed under better democratic control and shaped to produce better outcomes for our environment, will be a direct outcome of localisation processes.
} 


\section{PRESTON: CASE STUDY}

In the UK examples of localism have emerged out of crises in local economies, in response to the vacuum left by higher levels of government as industry has declined. Action had to be taken locally to rescue communities and cities from disrepute. Local wealth building is promoted by the Centre for Local Economic Strategies (CLES) in the UK. It focuses on 'anchor institutions' like housing organisations, schools and hospitals, and the role they play as employers, purchasers and propertyowners who are unlikely to leave the local areas. CLES examine how they can support smaller firms and build local wealth.

Preston City Council, working with CLES, followed the example of the Mondragon Cooperation in Spain and the 'Cleveland Model' in the USA by working with local institutions to strengthen their economy. Their community-wealth building agenda was a direct response to the systemic problems of austerity. Recognising wealth in their places through local institutions and the potential influence they have, the council worked with institutions to maximise the amount they spend on local procurement helping to boost local businesses and the creation of local cooperatives. The 'Preston Model' has gained widespread recognition in the British press as an example of a city taking back control and has inspired other local authorities to act.

In 2012 CLES and anchor institutions in Preston developed in-depth knowledge of local and socially responsible suppliers and worked to increase local economic and social benefits generated within their supply chains. This was to increase spending locally, to identify where money was leaking from the Lancashire economy, and to find ways to better benefit local workers and businesses. Through this approach the local economy was reorganised so that wealth is not extracted but broadly held and income is recirculated. The impact has been significant with the procurement spending retained within Preston increasing from £38.3million in 2012/12 to £112.3million in 2016/17 (CLES, 2019, July). By getting locally based institutions such as Community Gateway Housing Association, Preston College, Cardinal Newman College and the University of Lancashire, on board the council has managed to shift at least $£ 4 m-£ 5 m$ in public contracts back into the local economy (Brown \& O’Neill, 2016).

But beyond local procurement, other measures of quality of life have also improved in Preston. Unemployment in Preston in 2019 was 3.8\% down from 9\% in 2010 (NOMIS, n.d.). In the 2018 'Good Growth Cities Index' Preston the most rapidly improving urban area in the UK to live and work. This research used a range of measures beyond GDP including, employment, workers' pay, house prices, transport, the environment, work-life-balance and inequality (PwC, 2018). Further research could work to understand what residents of Preston feel the impact of having strong political agency has had on their prosperity and quality of life.

Matthew Brown of the Preston Council uses the examples of the Bank of North Dakota, Mondragón in the Basque Country and Emilia-Romagna in 
Bologna, to show how communities can create alternative ways, where they take control of their own destiny by putting local wealth under democratic control (Brown \& O’Neil, 2016). The Bristol Pound keeps wealth within local, independent businesses encouraging areas to become more creative holding on to a unique high street, rather than full of chain stores that are the same everywhere. Alternative to our standard economic approach where money leaks out of communities, these examples show that if you build an ownership strategy you can create a culture of control in a local community, that builds local wealth and encourages a more egalitarian economic system (Brown \& O’Neil, 2016).

Ownership is linked to an expression of our collective identity: 'through owning we belong, and through owning we become,'

(Singh, 2019)

The concept of placemaking is important to Iocalism (Layard, Milling \& Wakefield, 2013). Public spaces are essential for people to congregate and share ideas. We need parks, local icons, features that enable residents to feel a sense of pride, belonging and purpose. A sense of shared needs and collective ideas can strengthen social solidarity, one outcome of UBS (Coote \& Percy, 2020). Solidarity involves 'collective action towards a shared objective, to tackle a common challenge or adversary,' (Coote \& Angel, 2014: 3). This depends on people recognising a shared interest such as UBS or environmental sustainability, for example. The FE strengthens social solidarity, because it describes the essential aspects of the economy, helping people to live well and share prosperity. 


\section{CONNECTING UNIVERSAL BASIC SERVICES AND THE FOUNDATIONAL ECONOMY}

\subsection{WHAT IS THE FOUNDATIONAL ECONOMY}

The early history of local government shows how it was the main player in the public realm for organising essentials such as lighting, water, electricity, footpaths, and transport. This infrastructure was created through local leadership with the necessary support from above. Citizens have rights to these basic services because their public provisions underpin capacities and capabilities for all of us to live life. Aditya Chakrabortty (2019) writing for The Guardian announced that the UK is in the middle of a social infrastructure ${ }^{7}$ breakdown. Highlighted by the fact that a pub closes every 12 hours, since 2012760 youth clubs have closed and, lastly, nearly 130 libraries were shut last year. This is a loss of the institutions, part of daily life, that bring people together. This is social damage caused by neglect of our social infrastructure which is also part of what makes up the FE (FEC, 2018).

The FE framework emerged as response to fundamental human needs and incorporates the capability approach and the concept of the moral economy.

(FEC, 2018; Sayer, 2019)
It provides a powerful framework where we can redesign our economy by rethinking its actual purpose. The FE begins with people in their daily life, at home, at work, out and about in the streets.

The FE includes material infrastructure - like pipes and cables for utility distribution, water, electricity, public buildings, and retail banking. Providential services involve human interaction - essentially the entire welfare state - such as education, health, care and income maintenance (Heslop, Morgan \& Tomaney, 2019). Both kinds of infrastructure provide everyday necessities that are interdependent, that are taken for granted until they fail. These sectors have been neglected in debates about local industrial strategy but are essential across all levels of the economy, particularly in 'left behind' places (Tomaney \& Pike, 2018). Low-wage and low-skilled jobs characterise the FE as it has been pervasively mismanaged by policy makers distracted by hightech, 'next generation' industries. That which makes up the FE are immobile and usually free from competition and provide the social and material infrastructure that are a basic requirement for civilised life (FEC, 2018). Citizen tax revenues and unavoidable household expenditures sustain foundational activity (Bentham et al., 2013).

\footnotetext{
${ }^{7}$ Social infrastructure covers a range of services and facilities that meet local and strategic needs and contribute towards a good quality of life. It includes health provision, education, community, play, youth, recreation, sports, faith, and emergency facilities. Green infrastructure is also a key component of social infrastructure (Mayor of London, 2017: 202).
} 


\subsection{FE FOR FRAMING AND PRIORITISING UBS}

While the FE is about describing the essential aspects of the economy, UBS is about how you deliver enhanced quality of life to weather transformation. The FEC argue that the main role of public policy should be to secure the supply of basic services for all citizens (FEC, 2018: 3). Inherent to both FE and UBS is the understanding that wellbeing depends on social consumption of essential goods and services, from water supply and internet access, to schools and care homes (Coote \& Percy, 2020; IGP, 2017; 2019a; FEC, 2018). These are dependent on infrastructure and delivery networks, that are neither created nor renewed as income increases. They offer alternatives to orthodox debates on economic alternatives that are dominated by debates on industrial policy that privileges notions of research-oriented innovations that act as fuel for value extraction and rentier capitalism (Mazzucato, 2018).

UBS focuses on providential services and on areas where there has been significant public debate about inadequacy of universal service, namely childcare, adult social care, housing, transport and access to digital information. The idea of UBS is that it could be broadened in the future to account for emerging technologies and changing economic and social structures (Coote \& Percy, 2020).

Failure of foundational provision of these basic services is not a matter of economic inevitability but of political logic. It is not about productive constraints; it is about priorities and distribution in our societies. Public policy needs to recognise the limits of competition and the market and reassert the public obligations of business by rethinking the economy in terms of its foundations and prioritising UBS. Where the private sector is weak, public investment in quality infrastructure is important; aimed at addressing underlying social problems such as educational attainment and health inequities (CLES, 2017; Cumbers, 2016).

Local democracy needs to mean more than local delivery of national decisions by recognising that activities and services will work best when they reflect local political decisions. When the only fiscal vehicles left to councils are car-parking charges and planning permission fees it inhibits democracy, capacity and creativity (Hunt, 2016). For every pound taxed locally, only nine pence comes back from the Treasury and only five per cent of taxpayer's money is retained by local government. In Sweden it is more than a third, in France about half and in Canada it is 80 per cent (Hunt, 2016). Local governments need more fiscal autonomy. To discuss how this could be afforded we now look at taxation.

\subsection{TAXATION}

A new politics of redistribution is part of the solution to tackling financial and social inequalities and affording UBS. We live in a society of surpluses, but also one that sees taxation as a burden on enterprise. We need to use political will and economic capacity to use the surplus for foundational purposes to fund capital expenditure and practical capital investment in low-risk, long return foundational projects and service provision. The narrative that people resent paying taxes is inaccurate. Most people feel proud to contribute to society and recognise it as a crucial part of citizenship (Williamson, 2017). We need to conceive citizenship beyond territory and attach it to moral choices, through entitlement to UBS.

Wealth taxes can provide the necessary resources. The UK's wealth is tied up in property and land. A land value tax targeting immobile assets and unearned gains in wealth with explicit fiscal equalisation is central to achieving a geographically balanced economy (Ryan-Collins et al, 2017). People's willingness to pay taxes depends on their perception of the fairness of the taxation system. Evidence shows that those in the bottom decile pay a higher share of their income in tax than the top earners.

Institute for Public Policy Research (IPPR)'s Commission on Economic Justice argue that to deliver prosperity and justice for all the state 
must address social deficits through significant investment in social security systems and public services (Quilter-Pinner \& Hochlaf, 2019). International evidence supports this. When the IPPR ranked comparable countries, who spend up to $£ 1600$ per head more on health, education and welfare - in terms of social outcomes the UK lagged behind on most metrics. The UK has lower levels of life satisfaction, poorer health outcomes, higher levels of poverty and average educational outcomes. The IPPR calls on the UK government to match the European levels of social spending. To do this they argue that we need to pay more in taxes. Comparable European countries currently pay, on average, 41.8 per cent of GDP in taxes compared to 33.3 per cent in the UK in 2018 (Quilter-Pinner \& Hochlaf, 2019). Compared to other OECD countries the UK is a low-tax country and has considerable fiscal space for a UBS costing an additional 4 per cent of GDP (Coote \& Percy, 2020). The IGP's (2017) paper on UBS, lay out the evidence for the economic feasibility of UBS and how it can be paid for.

To charge more taxes people on middle incomes will have to feel that people on higher incomes are paying their fair share of taxes before they are willing to pay more themselves. Everybody will need to benefit from high quality services to form a coalition in favour of the 'investment state'. It is evident that funding social infrastructure is an investment like any other and will not only result in economic return but prosperity for all citizens (Quilter-Pinner \& Hochlaf, 2019).

The FEC (2018) argue for thinking of the economy as a system of revenue circulation, not as a system of wealth creation. The provision of UBS is crucial because limited providential access stunts lives and limits capabilities and possibilities for current and future generations. We have lost sight of this because of our preoccupation with income measures of poverty and coalescing growth with success. UBS offers a solution to the current neoliberal agenda, as it is a collective approach that reduces dependency on individual monetary income - rooted in beliefs in and benefits from equality, sustainability, efficiency, and solidarity (Coote \& Percy, 2020).

We have described the concept of localism in its myriads and argued for a restructuring towards progressive localism. We have reinterpreted the FE in light of arguments for UBS. Now we turn to discussing an industrial strategy that incorporates these ideas to ready the UK for the next economic and social transformation. 


\section{CONNECTING THESE CONCEPTS IN AN INDUSTRIAL STRATEGY FOR THE 21 ${ }^{\text {ST }}$ CENTURY}

The 2017 Industrial Strategy (HM Government, 2017) recognises that the growth potential of places around the UK can be unlocked through strategies tailored to the local context. It identifies five foundations of productivity - ideas, people, infrastructure, business environment and places - which attempt to tackle four grand challenges of artificial intelligence and the data economy, the future of mobility, clean growth and an ageing population. Central to this strategy are sector deals to drive innovation to tackle the UK's lagging productivity.

The current industrial strategy is a step in the right direction but has been criticised for biasing innovative sectors and neglecting other sectors such as hospitality and retail and for focussing almost entirely on London and the South-East of England, therefore doing little to tackle regional inequalities (Fothergill, Gore \& Wells, 2017; Strauss, 2019). 'The rhetoric is compelling,' says the New Economics Foundation, 'but the substance is lacking,' (Pendleton, 2017). It relies on wealth trickling down to the majority by high value jobs creating demand for services and by redistribution through tax-and-spend policies. The concentration on cities as growth engines, on commercial property development, technological innovation and highproductivity trading sectors ends up neglecting the middle- and low-income earners. The focus on the global competitiveness of the UK perpetuates the social, political and economic divisions.

The industrial strategy has said little about the services, production, consumption and social goods that sustain our daily lives, which are dismissed as being less productive and providing low-paid jobs to low-skilled workers. This misses the point. Firstly, productivity levels are not low but variable in different sectors. While we are preoccupied with knowledge-intensive business services and advancing manufacturing these jobs only employ an average of 4 per cent of the workforce in the EU. The FEC (2018) analysis found that employment in foundational activities accounted for 43.8 per cent of UK employment. When broken down regionally, employment in foundational activities in London is the lowest at 35 per cent, with all other regions being over 40 per cent. The North East had the highest percentage share at around 50 per cent. The FEC argue that these differences are caused by the larger diversity of jobs in London and the loss of manufacturing in areas like the North East. The largest number of foundational workers are employed in the state or para-state sectors of health, education and social care which employs 4.6m in England and Wales (Bentham et al., 2013).

Rather than competing with larger neighbouring places, 'left behind' regions need policies aimed at securing their FE (Tomaney \& Pike, 2018) and localising service delivery. Universal Basic Infrastructure is proposed in the Industrial Strategy (HM Government, 2017). The focus is on rail, energy, water and flood defence, fixed and mobile broadband and fibre, where investment is needed. These examples benefit from national provision as they are 'natural' monopolies, but infrastructure that could be efficiently provided locally includes education, care, housing, welfare, food production 
and supply, transport and care of natural resources. Local, place-based approaches can rebuild and enhance people's quality of life through improvements to infrastructure, accumulation of locally owned assets and stimulation of demandside policies. These approaches need participatory, deliberative, and multi-stakeholder models of decision-making because at their core they should be a response to the diverse local conditions and needs. They will need strong institutions and flexible and creative frameworks, a far cry from centrally imposed approach to devolution we have seen so far (Coote \& Percy, 2020; Tomaney, 2016; Wills 2016).

The role of UBS is not to boost private consumption through economic growth but to ensure quality provision of services that are focused on creating the environment for us all to live a life worth living. UK policies need to be directed at businesses within the FE which require them to meet social standards in a way that goes beyond claims of 'corporate social responsibility.' Local supply chains, in supermarkets for example, should not only meet the demand of consumers and shareholders, but also those of suppliers, workers and residents. This requires a shift towards politics that mobilises collectives at local and regional levels to press social and geographic agendas that matter to them (Bentham et al., 2013).

Businesses can be an asset on the supply side of the FE delivering UBS. Currently, there are no policies which ensure large businesses act local. Acting local could mean developing skills of local populations, selling regional products nationally or taking preventative responsibility for health through diet (FEC, 2018: 139). This is important as it shows how the FE and coinciding UBS are about more than utilities and public services. They are about institutions that contribute to secure livelihoods and deliver quality of life for citizens. An industrial strategy for the 2020's would ensure that all companies that engage in the foundations of our economy, providing UBS, work for the social benefit of society rather than solely for profits or industry.
Social licensing is proposed as one approach to corporate regulation, to rebalance corporate rights and responsibilities, making corporate social responsibility obligatory

(Froud \& Williams, 2019)

A social license is an agreement between a corporation seeking to work within a locality and the community that resides there. This should be applied to businesses in the FE who provide UBS where public and private providers are delivering essential goods and services that affect our societies functioning. Social licensing will only work if the shareholder value of corporations is undone (Mayer, 2018). Businesses should offer something social and meaningful in return for their right to extract cash from a place, ensuring companies are brought into public jurisdiction (Froud \& Williams, 2019). The majority of companies in the FE are sheltered from international competition, such as food distribution, public transport, housing, pipe and cable utilities, and water supply. These activities are economically anchored, with local networks and branches to deliver services and goods to the local population. They have a stable, non-cyclical demand, and providers in these activities are in mutually dependent relations with communities and users who depend on their services for wellbeing (Froud \& Williams, 2019). The potential here is being massively overlooked.

In May 2019 the Welsh Government launched an offer for a $£ 3 m$ fund to support businesses and organisations that operate within the FE (Welsh Government, 2019). This is clear recognition from a devolved government of the importance of the foundations of the Welsh economy and for the people who live there. They estimate that the FE comprises four out of 10 jobs and $£ 1$ in every three spent. The hope is that this fund will not only raise the awareness of the FE but spread prosperity to all communities in Wales (Welsh Government, 2019). 
In sectors such as care, health and education, we are less concerned with productivity and more concerned with the populations wellbeing, flourishment and opportunities for learning. The low pay attached to teaching or care, for example, reflects the low cultural value we attach it and so it is under-resourced. That which keeps us happy, healthy and safe involves collective consumption as a public good. These sectors depend on social investment, and their improvement requires good pay and conditions for the workers whose role in society crucial. An industrial strategy for the 2020's would recognise what we value most as a society through correcting the allocation of resources. Increasing our capacities and capabilities through local service delivery and enhancing local economies in the face of future uncertainty.

\subsection{THE FUTURE OF UBS}

UBS must adapt to the times, as the goods and services that individuals consider necessary to support life varies across place and time. Mobile phones are now ubiquitous and necessary to engage in modern life, where they once would not have been considered a foundational requirement. If we frame our economy in terms of its foundations it becomes clear what kinds of policy interventions could aid our social, economic and political future (Bentham et al., 2013). As well as established foundational areas, we need to plan for new foundational areas of the economy. This is where industrial policy can play a key role in future planning, for example, of telecommunications infrastructure and digital connectivity to health and care services.

Automation is speeding up a long-standing process by which wealth is gained less by society through employment and more through capital return (Piketty, 2014). As automation and Al continue to develop, they may reduce the share of income through labour. But human touch and care jobs cannot be automated and will increase with our aging population. Investment in these industries is an essential part of economic and social development and should be given equal weight to investment as high-end skills, infrastructure or property development.

In the coming future the FE may take on more. For example, data on nature, our social relationships, our personal lives and vast knowledge has been captured by corporations and commodified. This could be another part of the FE that could be rethought and reused by local ownership and decision-making. UBS will soon depend on information communication technology (Coote \& Percy, 2020). Oriol Estela (2019) of the Barcelona Strategic Metropolitan Plan calls for the FE to come up with a set of indicators that can show and monitor the degree of coverage and quality of essential services related to basic needs.

Rather than focusing on the tradeable, competitive economy the government should be more concerned with improving and decarbonizing the FE that employs 40 to 45 per cent of the UK workforce and is essential to daily life. The high carbon foundational sectors such as housing, transport and food account for more than 50 per cent of UK consumption-related emissions and thus must be a key area for decarbonisation through government regulation (Calafati et al. 2019). When rethinking the design of our economy, it is crucial we find a way to tackle climate change in order to render life on Earth sustainable. Coote and Percy (2020) argue that enhanced sustainability is one of the benefits of UBS. Firstly, because of the focus on human well-being over economic growth. Public provision is better at promoting sustainable consumption practices and policies than markets. There is evidence that collectively provided services have a smaller ecological footprint than privately funded alternatives (Coote \& Percy, 2020). Radically changing the systems of service provision to the local level supply chains, production and consumption, could assist in the radical transformation that is required to tackle environmental collapse.

Our wellbeing depends on the places we reside, they mark who we are and offer us opportunities to flourish or not. Our wellbeing within these 
places depends on achieving a basic level of accessibility, sociability and political agency. As feminist economists have long emphasised dependence on others is a normal part of every life (Fraser \& Gordon, 1994; Lister, 1990). An industrial strategy that focuses on quality of life through local delivery of UBS would acknowledge this. We need an industrial strategy that places more value on building capacities and capabilities, so elderly care, childcare, lifelong learning, for example, are fully recognised as important and sustaining for all of us. UBS is not just about people scraping by, it is about enhancing capacities to be able to face the next set of challenges posed by technological advancement. 


\section{CONCLUSION}

\section{PROSPERITY THROUGH THE LOCALISATION OF SERVICES}

To date, the promise of reviving local economies through devolutionist policies has not yet been fulfilled. The task is to create engines of investment to improve people's quality of life through regenerating local economies. This means investment in the infrastructure of care, education, transport and communication, our basic services - the foundations of our economy - to increase people's capacities and capabilities to support the economy at the local level. Everyone has the right to a good quality of life, and this cannot be provided by the market alone. It requires collective intervention through investment, regulation and subsidy of our basic services. UBS is rooted in shared needs, solidarity and collective responsibilities (Coote \& Percy, 2020).

Central government should be playing a major role in setting a broad vision, redistributing resources and ensuring access (Industrial Strategy Commission, 2017). This means local and regional governments need to be reinvented, empowered and reskilled to use their micro-level, everyday knowledge to develop in-depth and context-specific understandings of the FE and service delivery and to share intelligence about how to deal with common problems. Services should be provided by a range of organisations with diverse models of ownership, but with the same principles of provision for prosperity over market growth. With more devolved and reformed taxation, power can become more localised and services improved (Coote \& Percy, 2020).

Further research should work to provide tangible evidence to support UBS arguments through UKbased pilot studies. UBS offers a more holistic approach to the welfare state in the 21st century by tailoring types and scales of services according to peoples lived-experiences, priorities and socioeconomic context. This can only be done through ground-up and localised practices. 


\section{REFERENCE}

Angel, J. (2014). Moving Beyond the Market: a new agenda for public services. NEF. Retrieved from: https://b.3cdn.net/nefoundation/ d2675fe54cb1ce0203_Idm6bkjoz.pdf [Accessed on: 12 March 2020].

Bailey, D., Pitelis, C., \& Tomlinson, P. R. (2018). A place-based developmental regional industrial strategy for sustainable capture of co-created value. Cambridge journal of economics, 42(6), pp. 15211542.

Basic Income Earth Network. (2020). About basic income. BIEN. Retrieved from: https://basicincome. org/basic-income/ [Accessed on: 13 February 2020].

Bentham, J., Bowman, A., de la Cuesta, M., Engelen, E., Ertürk, I., Folkman, P., Froud, J., Johal, S., Law, J., Leaver, A., Moran, M. \& Williams, K. (2013). Manifesto for the Foundational Economy. CRESC Working Paper 131. Retrieved from: https:// foundationaleconomycom.files.wordpress.

com/2017/01/wp131.pdf [Accessed on: 19 September 2019].

Bevan, C. (2014). The Localism Act 2011: The hollow housing law revolution. The Modern Law Review, 77(6), pp. 964-982.

Boyle, D., Coote, A., Sherwood, C. \& Slay, J. (2013). Right Here, Right Now: Taking Co-production into the Mainstream. NESTA. Retrieved from: https:// media.nesta.org.uk/documents/right_here_right_ now.pdf [Accessed on: 10 February 2020].

Bradley, Q. \& Sparling, W. (2016). The impact of neighbourhood planning and localism on housebuilding in England. Housing Theory and Society. DOI: 10.1080/14036096.2016.1197852

Brown, M. \& O'Neill, M. (2016), The Road to Socialism is the A59: The Preston Model. Renewal, 24(2). Retrieved from: http://renewal.org.uk/articles/ the-road-to-socialism-is-the-a59-the-preston-model [Accessed on: 25 November 2019].

Calafati, L., Froud, J., Johal, S. \& Williams, K. (2019). Building foundational Britain: from paradigm shift to new political practice. Renewal, 27(2), pp. 13-23.

Cameron, D. (2010, July 19). Big Society Speech. Cabinet Office. Retrieved from: https://www.gov. uk/government/speeches/big-society-speech [Accessed on: 5 September 2019].

Chakrabortty, A. (2019, August 14). Britain's infrastructure is breaking down. And here's why no one's fixing it. The Guardian. Retrieved from: https:// www.theguardian.com/commentisfree/2019/aug/14/ britain-social-infrastructure-money-national-grid [Accessed on: 23 August 2019].

Clarke, N. (2013). Locality and localism: A view from British Human Geography. Policy Studies, 34(5-6), pp. 492-507.

CLES. (2017). What needs to be done: The manifesto for local economies. Retrieved from: https://cles.org.uk/publications/what-needs-to-bedone-the-manifesto-for-local-economies/ [Accessed on: 12 September 2019]. 
CLES. (2019, July). How we built community wealth in Preston. Retrieved from: https://cles.org.uk/ publications/how-we-built-community-wealth-inpreston-achievements-and-lessons/ [Accessed on: 18 September 2019].

CLES. (2019, August). On Devolution. Retrieved from: https://cles.org.uk/publications/cles-ondevolution/ [Accessed on: 18 September 2019].

Coote, A. \& Angel, J. (2014). Solidarity: Why it matters for a new social settlement. NEF working paper. Retrieved from: https://b.3cdn.net/ nefoundation/207c255d8a0c04cba0_sum6b1yy7. pdf [Accessed on: 11 March 2020].

Coote, A. \& Percy, A. (2020). The case for Universal Basic Services. Cambridge: Polity Press.

Crisp, R., Ferrari, E., Gore, T., Green, S., McCarthy, L., Rae, A., Reeve, K., \& Stevens, M. (2018). Tackling transport-related barriers to employment in low-income neighbourhoods. Joseph Rowntree Foundation. Retrieved from: https://www.jrforg. uk/report/tackling-transport-related-barriersemployment-low-income-neighbourhoods [Accessed on 12 September 2019].

Cumbers, A. (2016). Economic democracy. Reclaiming public ownership as the pragmatic left alternative. Juncture, 22(4): 324-328.

Davis, J. (2008). Double-Devolution or DoubleDealing? The Local Government White Paper and the Lyons Review. Local Government Studies, 34, pp. 3-22.

Department for Work and Pensions [DWP]. (2019). Households below average income (HBAl) statistics. Retrieved from: https://www.gov.uk/government/ collections/households-below-average-incomehbai--2 [Accessed on: 31 July 2019].

Department of Communities and Local Government. (2011, November). A plain English guide to the Localism Act. DCLG, UK. https://assets.publishing. service.gov.uk/government/uploads/system/ uploads/attachment_data/file/5959/1896534.pdf
(Accessed on: 11 July 2019)

Dorling, D. (2019). The curve of inequality and the Brexit Way. LSE Blogs. Retrieved from: https://blogs. Ise.ac.uk/brexit/2019/10/15/the-curve-of-inequalityand-the-brexit-way/ [Accessed on: 12 February 2020].

Economy. (n.d.). About. Retrieved from: https://www. ecnmy.org/about/ [Accessed on: 4 September 2019].

Estela, O. (2019). The Foundational Economy and strategic planning in Barcelona: reshaping the urban economy from the bottom up. Renewal, 27(2), pp. 33-39.

Featherstone, D., Ince, A., MacKinnon, D., Strauss, K. \& Cumbers, A. (2012). Progressive localism and the construction of political alternatives. Transactions of the Institute of British Geographers, 37(2), pp. 177-182

Findlay-King, L., Nichols, G., Forbes, D. \& Macfadyen, G. (2018). Localism and the Big Society: the asset transfer of leisure centres and libraries - fighting closures or empowering communities? Leisure Studies, 37(2), pp. 158-170.

Fleming, D.A. \& Goetz, S.J. (2011). Does local firm ownership matter? Economics Development Quarterly, 25, pp. 901-924.

Flick, U. (1994). Social representations and social construction of everyday knowledge: theoretical and methodological queries. Social Science Information, 33(2), pp. 179-197.

Fothergill, S., Gore, T. \& Wells, P. (2017). Industrial Strategy and the Regions: The shortcomings of a narrow sectoral focus. Centre for Regional Economic and Social Research, Sheffield Hallam University. Retrieved from: https://www4.shu.ac.uk/ research/cresr/sites/shu.ac.uk/files/cresr30thindustrial-strategy-regions.pdf [Accessed on: 13 September 2019].

Foundational Economy Collective. (2018). Foundational Economy. Manchester: Manchester 
University Press.

Fraser, N., \& Gordon, L. (1994). A Genealogy of Dependency: Tracing a Keyword of the U.S. Welfare State. Signs, 19(2), pp. 309-336.

Froud, J. \& Williams, K. (2019). Social Licensing for the Common Good. Renewal. Retrieved from: http:// www.renewal.org.uk/blog/social-licensing-for-thecommon-good [Accessed 25 November 2019].

Green, D. (2019). Coastal Housing Group: developing the Foundational Economy in South Wales. Renewal, 27(2), pp. 24-32.

Haldane, A. (2017). Everyday Economics [Speech]. Retrieved from: https://www.bankofengland.co.uk/-/ media/boe/files/speech/2017/everyday-economics.

Hall, D. (2019). Public ownership, benefits and compensation II: Pension funds and employee ownership of water and energy grid companies. Greenwich University, PSIRU. Retrieved from: https:// gala.gre.ac.uk/id/eprint/25940/7/25940\%20HALL_ Benefits_Costs_Water_Energy_Royal_Mail_Public_ Ownership_2_\%28AAM\%29_2019.pdf [Accessed 12 March 2020].

Hastings, A., Bailey, N., Gannon, M., Besemer, K., \& Bramley, G. (2015). Coping with the cuts? The Management of the worst financial settlement in living memory. Local Government Studies, 41, pp. 601-621.

Heslop, J., Morgan, K. \& Tomaney, J. (2019). Debating the Foundation Economy. Renewal, 27(2), pp. 5-12.

Hess, D.J. (2009). Localist movements in a global economy: Sustainability, justice, and urban development in the United States. Cambridge, MA: The MIT Press.

HM Government. (2017). Industrial Strategy White Paper. Retrieved from: https://assets.publishing. service.gov.uk/government/uploads/system/ uploads/attachment_data/file/664563/industrialstrategy-white-paper-web-ready-version.pdf
[Accessed on: 12 June 2019].

Hunt, T. (2016). Event Catch Up: Tristram Hunt MP on the Urban Century. Centre for Cities. https://www. centreforcities.org/podcast/event-catch-up-cityhorizons-tristram-hunt-mp-urban-century/ (Accessed on: 24 June 2019).

IGP. (2017). Social prosperity for the future: A proposal for Universal Basic Services. Retrieved from: https://ubshub.files.wordpress.com/2018/03/ social-prosperity-network-ubs.pdf [Accessed on: 6 January 2020].

IGP. (2019a). Universal Basic Services: Theory and Practice, A Literature Review. Retrieved from: https:// ubshub.files.wordpress.com/2019/05/ubs_report_ online.pdf [Accessed on: 4 January 2020].

IGP. (2019b). Rethinking prosperity for London: When citizens lead transformation. Retrieved from: https://static1.squarespace.com/ static/5a0c05169f07f51c64a336a2/t/5ce2d14014a13 2000171bcf1/1558368584590/LPI_Report_single.pdf [Accessed on 13 February 2020].

Industrial Strategy Commission. (2017). The Final Report of the Industrial Strategy Commission. Retrieved from: http://industrialstrategycommission. org.uk/wp-content/uploads/2017/10/The-FinalReport-of-the-Industrial-Strategy-Commission.pdf [Accessed on: 17 February 2020].

IPPR North. (2011). Community Assets First: The Implications of SLA for the Coalition Agenda. Church Action on Poverty, Oxfam, Urban Forum. Retrieved from: https://www.ippr.org/files/images/ media/files/publication/2011/10/Community-assetsfirst_Oct2011_8052.pdf [Accessed on: 11 October 2019].

Jackson, T. (2017). Prosperity without Growth: Foundations for the Economy of Tomorrow. 2nd ed. New York: Routledge.

Layard, A., Milling, J. \& Wakeford, T. (2013). Creative Participation in Place-making. Connected Communities. Retrieved from: https://prsc.org.uk/ 
wp-content/uploads/2019/01/AHRC-Final-ReportCreative-Participation_ANTONIA_LAYARD.pdf [Accessed on: 12 March 2020].

Levitas, R. (2012). The just's umbrella: Austerity and the Big Society in coalition policy and beyond. Critical Social Policy, 32(3), pp. 320-342.

Lister, R. (1990). Women, economic dependency and citizenship. Journal of Social Policy, 19(4), 445-467.

Maas, P. (1959). Divisions of powers: An areal analysis. In A., Maas (ed.), 'A theory of local government.' Glencoe, Illinois: The Free Press.

Mayer, C. (2018). Prosperity: Better Business Makes the Greater Good. Oxford: Oxford University Press.

Mayor of London. (2017). The Draft London Plan December 2017. Retrieved from: https://www. Iondon.gov.uk/sites/default/files/draft_london_plan_ chapter_5.pdf [Accessed on: 4 January 2019].

Mazzucato, M. (2018). Mission-Oriented Research and Innovation in the European Union. A Problemsolving Approach to Fuel Innovation-led Growth. European Commission. Retrieved from: https:// ec.europa.eu/info/sites/info/files/mazzucato_ report_2018.pdf [Accessed on: 30 September 2019].

McCurdy, C., Gardiner, L., Gustafsson, M., \& Handscomb, K. (2020). Painting the towns blue. Resolution Foundation. Retrieved from: https://www. resolutionfoundation.org/app/uploads/2020/02/ Painting-the-town-blue.pdf [Accessed on: 17 February 2020].

Moore, H.L. (2015). Global Prosperity and Sustainable Development Goals. Journal of International Development 27(6), pp. 801-15.

Moore, H.L. \& Woodcraft, S. (2019). Understanding Prosperity in East London: Local Meanings and "Sticky" Measures of the Good Life. City \& Society, 31(2), pp. 275-298.

Newman, J. (2013). Landscapes of antagonism: Local governance, neoliberalism, austerity. Urban Studies,
51(15), pp. 3290-3305.

NOMIS. (n.d.). Economically Active - Time Series. ONS. Retrieved from: https://www.nomisweb.co.uk/ reports/imp/la/1946157097/subreports/ea_time_ series/report.aspx? [Accessed on: 6 February 2020].

OECD. (2019). Making Decentralisation Work: A Handbook for Policy-Makers. OECD Multi-Level Governance Studies. OECD Publishing, Paris. Retrieved from: https://read.oecd-ilibrary.org/ urban-rural-and-regional-development/makingdecentralisation-work_g2g9faa7-en\#page1 [Accessed on: 2 August 2019].

ONS. (2020). Unemployment rate (aged 16 and over, seasonally adjusted). ONS. Retrieved from: https:// www.ons.gov.uk/employmentandlabourmarket/ peoplenotinwork/unemployment/timeseries/mgsx/ Ims [Accessed on: 12 February 2020].

Painter, J., Orton, A., Macleod, G., Dominelli, L. \& Pande, R. (2011). Connecting localism and community empowerment: research review and critical synthesis for the AHRC Connected Community Programme, Project Report. Durham University, Department of Geography and School of Applied Sciences. Retrieved from: http://dro.dur. ac.uk/9244/ [Accessed on: 5 September 2019].

Pendleton, A. (2017). _ The New Economics Foundation. Retrieved from: https://neweconomics. org/2017/11/rhetoric-fine-industrial-strategyunderwhelming [Accessed on: 17 September 2019].

Pike, A., Lee, N., MacKinnon, D., Kempton, L. \& Iddewala, Y. (2017). Job creation and inclusive growth in cities. Joseph Rowntree Foundation: York.

Piketty, T. (2014). Capital in the Twenty-First Century. Harvard University Press: Massachusetts.

PwC. (2018). Cities in the North West of England amongst fastest improving cities for the second year running - PwC's Good Growth for Cities index. PwC and Demos. Retrieved from: https://www. pwc.co.uk/who-we-are/regional-sites/north-west/ press-releases/cities-in-the-north-west-of-england- 
amongst-fastest-improving-ci.html [Accessed 6 February 2020].

Quilter-Pinner, H. \& Hochlaf, D. (2019). There Is An Alternative: Ending Austerity in the UK. IPPR Centre for Economic Justice. Retrieved from: https://www. ippr.org/files/2019-07/fairer-welfare-july-19.pdf [Accessed on: 15 July 2019].

Reeves, R. (2018). The everyday economy. Retrieved from: https://www.scribd.com/document/374425087/ Rachel-Reeves-The-Everyday-Economy [Accessed on: 10 September 2019].

Reeves, R., Tomaney, J. \& Williams, K. (2019,). The Everyday Economy: why it matters and how to rebuild it. LSE Blogs. Retrieved from: https://blogs. Ise.ac.uk/politicsandpolicy/the-everyday-economy/ [Accessed on: 13 September 2019].

Ryan-Collins, J., Lloyd, T., \& Macfarlane, L. (2017). Rethinking the Economics of Land and Housing. Zed Books: London.

Sayer, A. (2019). Moral economy, the Foundational Economy and decarbonisation. Renewal, 27(2), pp. 40-46.

Sen, A. (1999). Development as Freedom. Oxford University Press: Oxford.

Singh, A. (2019, March 11). The economics of belonging. RSA Journal. Retrieved from: https:// medium.com/rsa-journal/the-economics-ofbelonging-1d11c10c9a29n [Accessed on: 21 August 2019].

Strauss, D. (2019, March 19). MPs criticise bias towards innovative sectors in industrial strategy. Financial Times. Retrieved from: https://www.ft.com/ content/53aad05c-498c-11e9-8b7f-d49067e0f50d [Accessed on: 13 September 2019].

Tait, M. \& Inch, A. (2016). Putting Localism in Place: Conservative Images of the Good Community and the Contradictions of Planning Reform in England. Planning, Practice \& Research, 31(2), pp. 174-194.
The Economist. (2018). Rough sleeping in England has more than doubled. The Economist. https:// www.economist.com/britain/2018/03/08/roughsleeping-inengland-has-more-than-doubled (Accessed 15 July 2019)

Tomaney, J. (2016). Limits of devolution: Localism, economics and post-democracy. The Political Quarterly, 87(4), 546-552.

Trussell Trust. (2019). End of Year Stats. Retrieved from: https://www.trusselltrust.org/news-and-blog/ latest-stats/end-year-stats/ [Accessed on 31 July 2019].

UNDP. (2016). Sustainable Development Goals are a "roadmap for peace, dignity and prosperity." United Nations Development Programme. Retrieved from: https://www.undp.org/content/undp/en/ home/presscenter/pressreleases/2016/09/23/ sustainable-development-goals-are-a-roadmap-forpeace-dignity-and-prosperity-.html [Accessed on: 28 January 2020].

Verhaeghe, P. (2014). What about me? The struggle for identity in a market-based society. London: Scribe UK.

Wainwright, H. (2018). A New Politics from the Left. Cambridge: Polity Press.

Wallace-Stephens, F. (2019). Economic Insecurity: The case for a 21st century safety net. RSA \& Mastercard. Retrieved from: https://www.thersa. org/discover/publications-and-articles/reports/ economic-insecurity [Accessed on: 9 October 2019]

Ware, A. (2012). The Big Society and Conservative politics: Back to the future or forward to the past? The Political Quarterly special issue on the Big Society, 82, pp. 82-97.

Welsh Government. (2019). The foundational economy. Retrieved from: https://gov.wales/ foundational-economy [Accessed on: 19 September 2019]. 
Williamson, V.S. (2017). Read my lips: why Americans are proud to pay taxes. Princeton University Press.

Wills, J. (2016a). Locating Localism: Statecraft, Citizenship and Democracy. Policy Press: Bristol, UK.

YouGov. (2016). Rethinking Economics Survey Results. YouGov. Retrieved from: https://d25d2506sfb94s.cloudfront.net/ cumulus_uploads/document/5tw8cdop65/ RethinkingEconomicsResults_160229_

Media\&Economics_w.pdf [Accessed on: 3 January 2020).

YouGov. (2017). YouGov Survey Results. Retrieved from: https://d25d2506sfb94s.cloudfront. net/cumulus_uploads/document/w5uikOfcsy/ InternalResults_170215_TrustExpertise_W.pdf [Accessed on: 10 March 2020]. 
Research at the Institute for Global Prosperity at UCL aims to generate new insights about sustainable and inclusive prosperity and provide new models for developing and interpreting evidence.

Underlying our research is a rethinking of what we mean by prosperity. Prosperity must mean enabling people to flourish in ways beyond financial growth -and doing so equitably and sustainably, for humankind and the planet. We work with businesses, NGOs and citizens to produce interdisciplinary methodologies and problem-focused research.

For more information about our wide range of current projects and our innovative Masters and PhD programmes please see: www.ucl.ac.uk/bartlett/igp/ 


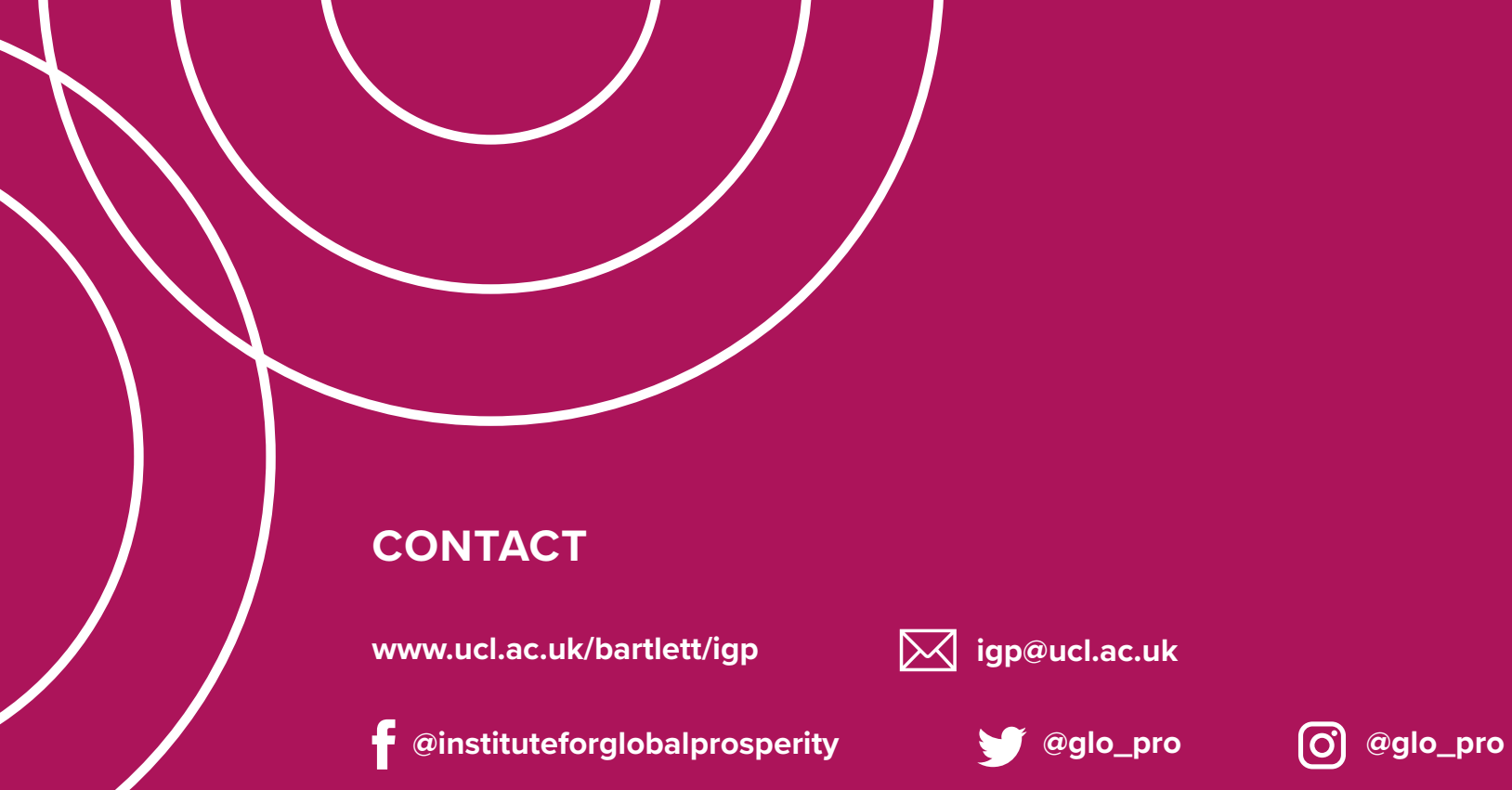

